\title{
SERPINB9 wt Allele
}

National Cancer Institute

\section{Source}

National Cancer Institute. SERPINB9 wt Allele. NCI Thesaurus. Code C104579.

Human SERPINB9 wild-type allele is located in the vicinity of 6p25 and is approximately 16 $\mathrm{kb}$ in length. This allele, which encodes serpin B9 protein, is involved in the negative regulation of serine protease activity. 